\title{
Lethal and sublethal effects of marine sediment extracts on fish cells and chromosomes
}

\author{
Marsha L. Landolt \& Richard M. Kocan \\ School of Fisheries, University of Washington; \\ Seattle, Washington 98195, USA
}

\begin{abstract}
The cost of conducting conventional chronic bioassays with every potentially toxic compound found in marine ecosystems is prohibitive; therefore short-term toxicity tests which can be used for rapid screening were developed. The tests employ cultured fish cells to measure lethal, sublethal or genotoxic effects of pure compounds and complex mixtures. The sensitivity of these tests has been proven under laboratory conditions; the following study used two of these tests, the anaphase aberration test and a cytotoxicity assay, under field conditions. Sediment was collected from 97 stations within Puget Sound, Washington. Serial washings of the sediment in methanol and dichloromethane yielded an organic extract which was dried, dissolved in DMSO and incubated as a series of dilutions with rainbow trout gonad (RTG-2) cells. The toxic effects of the extract were measured by examining the rate of cell proliferation and the percentage of damaged anaphase figures. Anaphase figures were considered to be abnormal if they exhibited non-disjunctions, chromosome fragments, or chromosome bridges. A second cell line (bluegill fry, BF-2) was also tested for cell proliferation and was included because, unlike the RTG-2 cell line, it contains little or no mixed function oxygenase activity. Of 97 stations tested, 35 showed no genotoxic activity, 42 showed high genotoxic activity $(P \leq .01)$ and the remainder were intermediate. Among the toxic sites were several deep water stations adjacent to municipal sewage outfalls and four urban waterways contaminated by industrial and municipal effluents. Extracts from areas that showed genotoxic effects also inhibited cell proliferation and were cytotoxic to RTG-2 cells. Few effects were noted in the MFO deficient BF-2 cells. Short term in vitro tests provide aquatic toxicologists with a versatile and cost effective tool for screening complex environments. Through these tests one can identify compounds or geographic regions that exhibit high cytotoxic or genotoxic potential.
\end{abstract}

\section{INTRODUCTION}

Puget Sound, located in the state of Washington (USA), is a fjordlike basin that is connected to the North Pacific Ocean by the Strait of Juan de Fuca. Circulation in Puget Sound is estuarine in nature, being driven by freshwater inputs, gravitational convection, tides and winds. This dynamic pattern of circulation in an area otherwise protected from environmental extremes has led to the development of a productive and diverse ecosystem. The high productivity, strategic location, and natural beauty of Puget Sound combine to form a key economic resource in the Pacific Northwest region of the United States, and as a consequence of its importance to the fisheries, transportation, defence and recreational industries of the area this body of water has received intensive study over the past decade.

Out of this study has grown an awareness that some portions of Puget Sound are heavily contaminated with toxic chemicals (Dexter et al., 1981). This realization has 
come both directly, through measurement of contaminant levels in sediment, water and biota, and indirectly, through the detection of pathological changes present in resident fish species. Although a variety of pathological conditions have been found in Puget Sound fishes (e.g. fin erosion, increased parasite load, branchial inflammation), particular attention has been focused on the presence of hepatocellular and cholangiocellular carcinomas in certain species belonging to the pleuronectid family of flatfish (McCain et al., 1977; Pierce et al., 1978). The incidence of these neoplasms appears to be geographically focal with affected fish occurring only in those portions of Puget Sound that are primary recipients of municipal or industrial effluent.

Although the evidence strongly suggests that a link exists between the presence of these tumors and exposure to chemical contaminants, a clear cause and effect relationship has been difficult to prove. The enormous array of chemicals present in marine water and sediment, the genetic and physiological diversity found among wild fish and the frequently long latent period existing between tumor initiation and tumor production make in vivo laboratory testing a formidable undertaking.

The difficulties inherent in applying traditional bioassay techniques to the solution of this problem prompted us to ask whether an in vitro approach might be used to detect the presence of genotoxic, and thereby potentially mutagenic or carcinogenic, compounds in marine sediments. If such a technique were feasible we hypothesized that it could be used as a rapid and inexpensive screening mechanism for identifying those sediments and sediment fractions meriting more intensive analytical and biological testing.

In the current study cultured fish cells were used to test organic extracts of sediment collected from 97 sites within Puget Sound. The use of fish cell cultures allowed observation of toxic effects directly on cells by eliminating the influence of the integrated defense mechanisms found in an intact animal (e.g. excretion, detoxification, storage, nonspecific binding). Testing in the present study focused on two endpoints: cell reproduction (both inhibition of cell proliferation and cell death) and induction of anaphase aberrations. The results of this study indicated that in vitro assays using cultured fish cells could be used to effectively identify areas within Puget Sound which contained sediments bearing high cytotoxic or genotoxic potential.

\section{MATERIALS AND METHODS}

Collection sites. Sediment was collected from 97 sites within Puget Sound (Fig. 1). Special emphasis was placed on urbanized embayments and estuaries adjacent to the cities of Seattle (Elliott Bay, 18 sites), Tacoma (Commencement Bay, 6 sites), and Bremerton (Sinclair Inlet, 12 sites), and on industrialized waterways feeding into Elliott Bay (East and West Waterways and upper Duwamish river, 19 sites) and Commencement Bay (Blair, City, Sitcum and Hylebos Waterways, 31 sites). A non-urbanized reference area (Port Madison, 6 sites) and a reference area located outside of central Puget Sound (Birch Bay, 5 sites) were also included.

Sediment collection. Sediment samples were collected using a 0.1 square meter van Veen grab modified with top screens and rubber flaps to minimize surface sediment disturbance. Sediments were removed by means of a scoop using a polyethylene bag stretched over an aluminium frame. From $3-5 \mathrm{~kg}$ (wet weight) of sediment was 


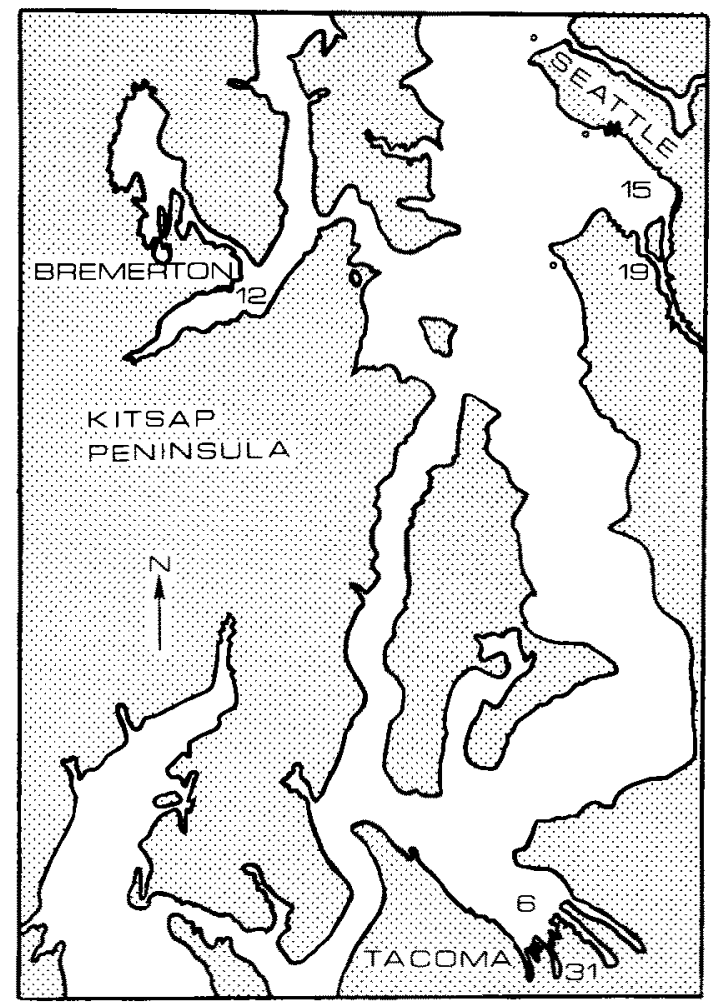

Fig. 1. Urban embayments and waterways in Puget Sound, Washington, USA, from which sediment samples were collected. Numbers indicate the number of stations located within each site.

Reference areas were located north of the boundaries of this chart and are not shown

collected and immediately homogenized by thorough kneading. Aliquots were transferred to solvent rinsed glass jars $(475 \mathrm{ml})$ with teflon cap liners and then frozen.

Preparation of sediment extracts. Each sample was thawed, rehomogenized by careful stirring and an aliquot (approximately $150 \mathrm{~g}$ wet weight) was transferred to a tared, solvent-cleaned, stainless steel centrifuge bottle $(315 \mathrm{ml})$ for weighing. The sample was then serially extracted with pesticide-grade solvents using the procedure of Malins et al. (1980) as summarized below.

Methanol $(50 \mathrm{ml})$ was added to each bottle, which was tightly capped and shaken for $2 \mathrm{~min}$ followed by centrifugation at $2000 \mathrm{rpm}$ for $5 \mathrm{~min}$. The clear solvent was decanted into a 11 separatory funnel. The procedure was repeated twice and the extracts were combined.

One hundred $\mathrm{ml}$ of a dichloromethane/methanol $(2: 1 \mathrm{v} / \mathrm{v})$ solution were added to the centrifuge bottle and shaken vigorously for $2 \mathrm{~min}$. The bottle was then placed in a shaker table for $18 \mathrm{~h}$, the sediment was settled by centrifugation ( $2000 \mathrm{rpm}, 5 \mathrm{~min}$ ) and the solvent was decanted and combined with the methanol extract. A second $100 \mathrm{ml}$ aliquot of the dichloromethane/methanol was added, the bottle shaken and placed on the shaker table for $6 \mathrm{~h}$ and the solvent decanted after centrifugation. 
The remaining sediment was shaken vigorously $(2 \mathrm{~min})$ with dichloromethane $(30 \mathrm{ml})$, centrifuged and the solvent decanted. Dichloromethane $(100 \mathrm{ml})$ was again added, the bottle was shaken on a shaker table $(18 \mathrm{~h})$, centrifuged and the solvent decanted. The procedure was repeated using $30 \mathrm{ml}$ dichloromethane and the sediment was then discarded.

In a separatory funnel $500 \mathrm{ml}$ distilled water were added to the combined solvents. The funnel was swirled and inverted with frequent venting for $2 \mathrm{~min}$. The phases were allowed to separate and the dichloromethane layer was drained into a separatory funnel. The aqueous layer was reextracted twice with dichloromethane $(20 \mathrm{ml})$ and the remainder was discarded. This procedure was repeated twice.

The combined dichloromethane fractions were drained through $20 \mathrm{~g}$ of combusted and washed anhydrous sodium sulfate and discharged into a Kuderna-Danish flask $(500 \mathrm{ml})$ with a $15 \mathrm{ml}$ receiver. Boiling chips were added to the flask and a 3-ball Snyder column was placed on top. The solvent volume was reduced to $5 \mathrm{ml}$ on a hot water bath. When cooled the sides were rinsed into the receiver with dichloromethane. The contents of the receiver were quantitatively transferred to a tared conical centrifuge tube and the sample was taken almost to dryness on a hot water bath. The centrifuge tubes were wrapped in aluminium foil, placed in a dessicator with their stoppers open slightly and stored until a constant weight was achieved upon reweighing the tube. The weight was the amount of extractable organic material.

Extracts were treated with $1 \mathrm{ml}$ spectrophotometric grade dimethylsulfoxide (DMSO) for $24 \mathrm{~h}$ with frequent stirring on a vortex mixer. The DMSO was then removed to a glass vial and used as a stock solution. Based on dry weight, the samples were diluted to a concentration of $20 \mathrm{mg} / \mathrm{ml}(5 \mu \mathrm{l}=100 \mu \mathrm{g})$. Both the stock solution and $20 \mathrm{mg} / \mathrm{ml}$ solution were stored in the dark under nitrogen until applied to the cell cultures.

Since not all of the extracted material dissolved in the DMSO, the tubes were reweighed at the completion of testing to estimate the amount actually applied to the cell cultures.

Cell proliferation. Rainbow trout gonad (RTG-2) cells were cultured in Eagle's minimum essential medium (MEM) supplemented with $10 \%$ fetal bovine serum (FBS), glutamine (100 mM), non-essential amino acids $(1 \mathrm{mM})$, sodium bicarbonate (8.9 mM), penicillin (15 units $/ \mathrm{ml})$ and streptomycin $(15 \mu \mathrm{g} / \mathrm{ml})$. A pH of 7.0-7.3 was maintained by cultivation in $5 \%$ carbon dioxide. For each of 97 sediment extracts, $5 \times 10^{4}$ cells were plated onto the wells of a Costar dish (24 wells $/$ dish; $2 \mathrm{~cm}^{2}$ wells) and the unknown extract added to a final concentration of $100,50,10$ and $1 \mu \mathrm{g} / \mathrm{ml}$ of culture medium ( $0.5 \%$ DMSO total for all concentrations). The cells were exposed to the extracts for $72 \mathrm{~h}(18 \mathrm{C})$. The maximum tolerable (non-toxic) concentration of sediment extract was determined by the presence of actively dividing cells (mitotic figures), as seen in the living cultures when examined with a phase contrast microscope. This maximum non-toxic concentration as well as one lower dilution were used for the final cell exposures and anaphase scoring.

MFO activation. Based on the results of the cell proliferation studies 22 stations were selected for further testing. These stations represented a range of relative toxicity scores and were taken from most of the major geographic areas.

For this study rainbow trout gonad (RTG-2) cells which possess an active MFO 
system, and bluegill fry cells (BF-2), which do not have an active MFO system, were cultured in Leibovitz L-15 medium (pH 7.1-7.3) supplemented with $10 \%$ fetal calf serum and antibiotics. The cells were seeded into Corning 2 square $\mathrm{cm}$ multiwell plates at densities of 20,000 (RTG-2) and 90,000 (BF-2) cells per well and incubated at 18 and $25 \mathrm{C}$ respectively. After the cells had settled and attached, six dilutions of each extract were prepared in duplicate in the culture medium and added to the cell cultures. These dilutions were based on the total organic weight of the samples and were later corrected to reflect the concentrations of soluble extract. Final extract concentrations were determined by first exposing cell cultures to a range of concentrations to determine the highest non-toxic dose which permitted cell proliferation. This high dose was then used to make all subsequent dilutions to which the cultures would ultimately be exposed.

Control cultures consisted of six replicates of untreated cells, six replicates of solvent (0.5\% DMSO) treated cells, two replicates of an extraction blank, which consisted of residues of all of the solvents used during sediment extraction, and six replicates of $0.5 \mu \mathrm{g} / \mathrm{ml}$ benzo(a)pyrene (BAP) treated cells for comparison with a known toxicant.

After a 96 -h exposure period the cultures were rinsed once with buffered saline $(\mathrm{pH} 7,1)$ to remove any unattached dead cells. The remaining live cells were removed for counting by the addition of $0.01 \%$ EDTA/trypsin to each culture well. The total number of cells in each well was determined using an electronic particle counter (Coulter, Model ZBI).

Mean number of cells for each treatment was compared to the mean control values $(96 \mathrm{~h}$ controls $=100 \%)$ and any concentration which reduced the final cell count by $20 \%$ (equivalent to 2 standard deviations of the mean and thus representing $95 \%$ confidence limits) or more was considered inhibitory. When cell numbers at the end of $96 \mathrm{~h}$ were below the starting cell number, that concentration of extract was considered to be cytotoxic (i.e. produced cell death).

An aphase aberrations. Based on the results of the cell proliferation studies, working dilutions of the 97 extracts were prepared. RTG-2 cells from stock cultures were grown using the methods described for cell proliferation studies and plated onto acid cleaned glass slides in $1 \mathrm{ml}$ of culture medium. The slides were then incubated overnight in square Petri plates and the appropriate sample extract was added to the culture medium the following morning. Two slides per dilution of each extract were then incubated for $48 \mathrm{~h}$ at $18 \mathrm{C}$, following which the slides were removed from the culture medium, rinsed, fixed in methanol : acetic acid $(3: 1)$ for $1 \mathrm{~h}$, air dried and stained with $3 \%$ Giemsa stain in Sorenson's buffer ( $\mathrm{pH} 6.8)$. A minimum of 100 anaphases per slide were microscopically examined ( $470 \times$ magnification) for each sediment concentration and the percentage of normal and aberrant anaphases were recorded. Controls consisted of: (1) a set of untreated cells, (2) a set treated with $0.5 \%$ spectrophotometric grade DMSO, and (3) a set treated with $0.25 \mu \mathrm{g} / \mathrm{ml}$ benzo(a)pyrene. From these controls, determinations were made of the spontaneous background level of anaphase aberrations, the effect, if any, of the solvent used in exposures, and whether the system responded to a concentration of known mutagen previously shown to be capable of producing high levels of aberrations in these cells.

Throughout the experiments the various types of aberrations observed were classified on the basis of previously described abnormalities (Nichols et al., 1977; Kocan et al., 1982). 


\section{RESULTS}

\section{Cell proliferation}

The concentrations of sediment extract which exhibited inhibitory effects on the proliferation of cultured RTG-2 cells ranged from $0.75 \mu \mathrm{g} / \mathrm{ml}$ to $40 \mu \mathrm{g} / \mathrm{ml}$ with $76 \%$ of the extracts showing inhibitory activity between 1 and $15 \mu \mathrm{g} / \mathrm{ml}$. All extracts were toxic and lethal at concentrations over $40 \mu \mathrm{g} / \mathrm{ml}$,

A relative toxicity score of $0-5$ was assigned to each station based on the concentration at which the sediment extract was toxic to RTG-2 cells. The scores were assigned as follows: $5=$ highly inhibitory (toxic at $0-1 \mu \mathrm{g} / \mathrm{ml}$ ), $4=$ highly inhibitory (toxic at $1.1-5 \mu \mathrm{g} / \mathrm{ml}$ ), $3=$ inhibitory (toxic at $5.1-10 \mu \mathrm{g} / \mathrm{ml}$ ), $2=$ inhibitory (toxic at $10.1-15 \mu \mathrm{g} /$ $\mathrm{ml}$ ), $1=$ slightly inhibitory (toxic at $15.1-20 \mu \mathrm{g} / \mathrm{ml}$ ), $0=$ questionable effect (toxic at $20-40 \mu \mathrm{g} / \mathrm{ml})$.

Of the 97 stations tested 30 were highly inhibitory (Score of $4-5$ ), 43 were inhibitory (Score of 2-3) and 23 were slightly inhibitory (Score of $0-1$ ). The highly toxic stations were not clustered within a given area, but rather were found in a variety of sites

Table 1. Effect of Puget Sound sediment extracts on proliferation of rainbow trout gonad (RTG-2) cells

\begin{tabular}{|c|c|c|c|c|}
\hline Site & $\begin{array}{c}\text { No. of } \\
\text { stations }\end{array}$ & $\begin{array}{c}\text { Highly } \\
\text { inhibitory } \\
\text { (score } 4-5)^{*}\end{array}$ & $\begin{array}{l}\text { Moderately } \\
\text { inhibitory } \\
\text { (score 2-3) }\end{array}$ & $\begin{array}{c}\text { Slightly } \\
\text { inhibitory } \\
\text { (score 0-1) }\end{array}$ \\
\hline \multicolumn{5}{|l|}{ Seattle } \\
\hline Elliott Bay & 18 & $10^{* * *}$ & 4 & 4 \\
\hline West Waterway & 4 & 1 & 2 & 1 \\
\hline East Waterway & 4 & 0 & 3 & 1 \\
\hline Duwamish River & 11 & 3 & 7 & 1 \\
\hline \multicolumn{5}{|l|}{ Tacoma } \\
\hline Commencement Bay & 6 & 3 & 3 & 0 \\
\hline Hylebos Waterway & $13^{* *}$ & 1 & 7 & 4 \\
\hline Blair Waterway & 9 & 4 & 3 & 2 \\
\hline Sitcum Waterway & 4 & 1 & 3 & 0 \\
\hline City Waterway & 4 & 1 & 0 & 3 \\
\hline Puyallup River & 1 & 0 & 1 & 0 \\
\hline \multicolumn{5}{|l|}{ Bremerton } \\
\hline Sinclair Inlet & 12 & 0 & 5 & 7 \\
\hline \multicolumn{5}{|l|}{ Reference Areas } \\
\hline Port Madison & 6 & 3 & 3 & 0 \\
\hline Birch Bay & 5 & 3 & 2 & 0 \\
\hline \multicolumn{5}{|c|}{$\begin{array}{l}\text { * Score of } 4-5=\text { toxic at concentrations of } 0-5 \mu \mathrm{g} / \mathrm{ml} \text {; score of } 2-3=\text { toxic at concentrations of } \\
5.1-15 \mu \mathrm{g} / \mathrm{ml} ; \text { score of } 0-1=\text { toxic at concentrations of } 15.1-40 \mu \mathrm{g} / \mathrm{ml} \\
\cdots \text { Data were not recorded for one station } \\
\cdots \text { Values indicate the number of stations at each location }\end{array}$} \\
\hline
\end{tabular}


including the reference areas. Table 1 summarizes the relative inhibitory effects of the various sediment extracts.

\section{MFO activation}

Based on the results of the cell proliferation studies, 22 stations with toxicity scores ranging from 0-4 were selected for further testing using two cell lines rather than one.

Table 2 summarizes the results from control culture replication. Untreated, DMSO treated and extraction blank treated cultures of both RTG-2 (MFO positive) and BF-2 (MFO negative) cells exhibited an approximately $150 \%$ increase in cell number after 96 hours incubation. Benzo(a)pyrene had no effect on BF-2 cells, but it reduced proliferation of RTG-2 cells by approximately $60 \%$, thereby indicating the ability of RTG-2 cells to metabolize (via the MFO system) this inert compound and form toxic products.

Table 2. Summary of cell proliferation in control cultures (including standard deviations)

\begin{tabular}{|c|c|c|c|c|c|}
\hline \multirow{2}{*}{ Cell line } & \multirow{2}{*}{$\begin{array}{l}\text { Number of } \\
\text { cells at start }\end{array}$} & \multicolumn{4}{|c|}{ Number of cells after $96 \mathrm{~h}$ (\% increase) } \\
\hline & & $\begin{array}{c}\text { Untreated } \\
\text { control }\end{array}$ & $\begin{array}{l}\text { DMSO } \\
\text { control }\end{array}$ & $\begin{array}{c}\text { Extraction } \\
\text { blank }\end{array}$ & $\begin{array}{c}\text { BAP } \\
\text { control }\end{array}$ \\
\hline RTG-2 & 20,000 & $\begin{array}{r}49,000 \\
\pm \quad 4,100 \\
(145 \%)\end{array}$ & $\begin{array}{r}50,300 \\
\pm \quad 4,100 \\
(151 \%)\end{array}$ & $\begin{array}{r}45,400 \\
(127 \%)\end{array}$ & $\begin{array}{l}31,800 \\
(59 \%)\end{array}$ \\
\hline $\mathrm{BF}-2$ & 90,000 & $\begin{array}{r}240,000 \\
\pm 30,000 \\
(167 \%)\end{array}$ & $\begin{array}{r}252,000 \\
\pm 30,000 \\
(180 \%)\end{array}$ & $\begin{array}{l}242,000 \\
(169 \%)\end{array}$ & $\begin{array}{l}246,000 \\
(173 \%)\end{array}$ \\
\hline
\end{tabular}

A relative toxicity score of $0-5$ was assigned to each station based on the concentration at which the sediment extract from that station was toxic to cells. The scoring system was the same as that used in the cell proliferation studies with the following modifications: $2=$ toxic at $10-19.9 \mu \mathrm{g} / \mathrm{ml}, 1=$ toxic at $20 \mu \mathrm{g} / \mathrm{ml}$ and above, $0=$ no effect.

BF-2 cultures showed little response to any of the 22 sediment extracts (Table 3 ). Significant decreases in cell proliferation were observed at only five stations and then only at the highest concentration tested $(50-69 \mu \mathrm{g} / \mathrm{ml})$. In contrast RTG-2 cultures exhibited reductions in cell numbers relative to controls at all stations and showed a typical dose response to increasing concentrations of extract (Fig. 2). The concentrations of sediment extract which exhibited toxic effects on RTG-2 cells ranged from $0.87-69 \mu \mathrm{g} /$ ml (Table 3).

As noted in the cell proliferation studies, stations containing toxic extracts did not cluster within urban waters, but rather were found equally in urban and reference areas.

\section{Anaphase aberrations}

Baseline levels of abnormalities were determined by examining 100 anaphase cells from 10 separate untreated or solvent treated cultures. From these 1,000 cells a mean abnormality frequency of $11.5 \%$ (standard deviation 3.02) was found. By using two 
Table 3. Comparative effect of Puget Sound sediment extracts on proliferation of MFO+ (RTG-2) and $\mathrm{MFO}-(\mathrm{BF}-2)$ cells

\begin{tabular}{|c|c|c|c|c|c|c|c|c|c|}
\hline \multirow[b]{2}{*}{ Seattle } & \multicolumn{7}{|c|}{ Sediment concentration tested $(\mu \mathrm{g} / \mathrm{ml})$} & \multicolumn{2}{|c|}{ Relative toxicity score } \\
\hline & \multicolumn{9}{|c|}{ Seattle } \\
\hline \multirow[t]{5}{*}{ Elliott Bay } & A & 0.8 & 4.2 & 8.4 & 21 & 42 & $63^{*}$ & 3 & 0 \\
\hline & B & 0.6 & 2.8 & 5.6 & 14 & 28 & $\overline{42}$ & 1 & 0 \\
\hline & $\mathrm{C}$ & 0.8 & 4.0 & $\underline{8.1}$ & 20 & 40 & 61 & 3 & 0 \\
\hline & D & 0.6 & 3.1 & 6.3 & 16 & 32 & 47 & 2 & 0 \\
\hline & $\mathrm{E}$ & 0.9 & 4.6 & 9.2 & 23 & 46 & {$[69$} & 4 & 1 \\
\hline West Waterway & & 0.5 & 2.5 & 5.1 & 13 & 26 & 38 & 2 & 0 \\
\hline East Waterway & & 0.5 & $\underline{2.7}$ & 5.3 & 13 & 27 & 40 & 4 & 0 \\
\hline \multirow[t]{2}{*}{ Duwamish River } & A & 0.6 & 2.9 & 5.9 & 15 & 30 & 44 & 4 & 0 \\
\hline & B & 0.4 & 1.9 & 3.9 & 8 & 20 & 29 & 4 & 0 \\
\hline \multicolumn{10}{|l|}{ Tacoma } \\
\hline Commencement Bay & & 0.5 & 2.4 & 4.8 & 12 & 24 & 36 & 1 & 0 \\
\hline \multirow{4}{*}{ Hylebos Waterway } & A & 0.6 & 2.8 & 5.7 & 14 & 29 & $\overline{43}$ & 1 & 0 \\
\hline & B & 0.3 & 1.8 & 3.5 & 9 & 18 & 26 & 2 & 0 \\
\hline & C & 0.4 & 1.8 & 3.6 & 9 & 15 & 27 & 2 & 0 \\
\hline & D & 0.4 & 1.9 & 3.9 & 10 & 20 & 29 & 1 & 0 \\
\hline \multirow[t]{2}{*}{ Blair Waterway } & A & 0.9 & 4.4 & 8.7 & 22 & 44 & 65 & 5 & 1 \\
\hline & B & 0.4 & 2.2 & 4.3 & 11 & 22 & 32 & 4 & 0 \\
\hline \multirow{3}{*}{$\begin{array}{l}\text { Sitcum Waterway } \\
\text { City Waterway }\end{array}$} & & 0.7 & 3.4 & 6.7 & 17 & 34 & 50. & 2 & 1 \\
\hline & A & 0.8 & 4.3 & 8.5 & 21 & 43 & [64] $\cdots$ & 1 & 1 \\
\hline & B & 0.9 & 4.5 & 8.9 & 22 & 45 & 67 & 1 & 0 \\
\hline \multicolumn{10}{|l|}{ Bremerton } \\
\hline \multirow[t]{2}{*}{ Sinclair Inlet } & A & 0.5 & 2.7 & 5.3 & 13 & 27 & 40 & 2 & 0 \\
\hline & $\mathrm{B}$ & 0.5 & $\underline{2.8}$ & 5.5 & 14 & 28 & $\overline{41}$ & 4 & 0 \\
\hline \multicolumn{10}{|l|}{ Reference Areas } \\
\hline Port Madison & & 0.7 & 3.7 & 7.3 & 18 & 37 & 55 - * & 2 & 1 \\
\hline \multicolumn{10}{|c|}{$\begin{array}{l}\text { * Underlined values are those which were toxic for RTG-2 cells } \\
* \text { Boxed values are those which were toxic for BF-2 cells }\end{array}$} \\
\hline
\end{tabular}

standard deviations from the mean to represent a 0.05 confidence limit, and three standard deviations to represent a 0.01 confidence limit, assessments were made as follows: anaphase abnormality frequencies of $18-20 \%(\mathrm{P} \leq 0.05)$ were considered to be significant and frequencies of $21 \%$ or greater $(\mathrm{P} \leq 0.01)$ were considered to be highly significant. These values correspond with t-test values obtained from dose response tests that were previously performed on this cell line using several known mutagenic/ carcinogenic compounds (Kocan et al., 1982). Abnormality frequencies of $17 \%$ or lower were not considered to be significantly different from control values. The result of exposure of the RTG-2 cells to the positive control [0.25 $\mu \mathrm{g}$ benzo(a)pyrene per $\mathrm{ml}$ of culture medium] was an anaphase aberration frequency of $50-65 \%$.

The classification of abnormal anaphases followed that presented by Nichols et al. (1977). Since the significance of the various forms of aberration is not known, the 


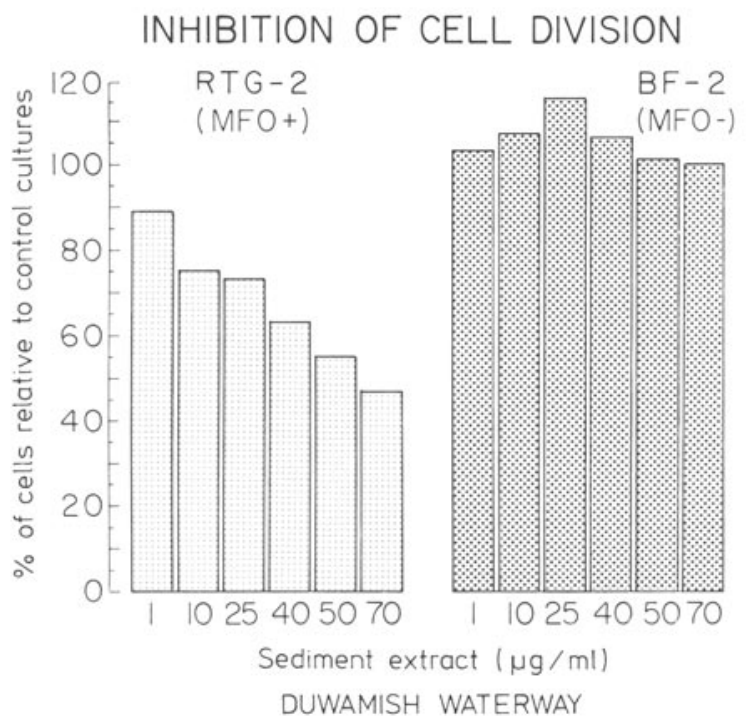

Fig. 2. Comparative effect of Puget Sound sediment extracts on proliferation of rainbow trout gonad (RTG-2) and bluegill fry (BF-2) cells. Representative data taken from a single station (Duwamish River) illustrate the dose response of $\mathrm{MFO}+$ cells (RTG-2) to increasing concentrations of extract, as well as the absence of a dose response in $\mathrm{MFO}-$ cells (BF-2)

aberrations were recorded as falling into one of two major groupings: chromosomal fragments, chromosomal bridges.

Of the 97 stations tested highly significant $(\mathrm{P} \leq 0.01)$ increases in mitotic damage were observed in 43 sediment samples, significant $(P \leq 0.05)$ increases were found in 18 samples, and no changes were found in 36 samples. Areas of highest genotoxicity were clustered primarily in the heavily industrialized urban areas, with only 1 of 11 reference sites being highly significant (Table 4).

\section{DISCUSSION}

The data obtained during this study clearly indicated that extracts of sediments collected from a number of locations in Puget Sound were capable of causing cytotoxicity and chromosomal damage in cultured fish cells.

\section{Cell proliferation}

Although $76 \%$ of the sediment extracts were inhibitory to RTG-2 cell proliferation at concentrations of $1-15 \mu \mathrm{g} / \mathrm{ml}$ (toxicity score of $2-4$ ), only $42 \%$ of the stations showed a positive correlation between cytotoxicity and genotoxic injury (anaphase aberrations). Further, stations with high cytotoxic potential were found in equal frequency in relatively clean and in highly contaminated areas. It appears that the cytotoxicity assay measures a wide variety of mutagenic and non-mutagenic compounds that can inhibit cell proliferation or cause cell death. The fact that cell proliferation was inhibited by extracts from many different sites does not indicate that the same compounds are present 
Table 4. Effect of Puget Sound sediment extracts on induction of anaphase aberrations in rainbow trout gonad (RTG-2) cells

\begin{tabular}{|c|c|c|c|c|}
\hline Site & No. stations & $\begin{array}{l}\text { Highly } \\
\text { significant } \\
(\mathrm{P}<0.01)\end{array}$ & $\begin{array}{c}\text { Significant } \\
(\mathrm{P}<0.05)\end{array}$ & $\begin{array}{c}\text { Not } \\
\text { significant }\end{array}$ \\
\hline \multicolumn{5}{|l|}{ Seattle } \\
\hline Elliott Bay & 18 & $11^{*}$ & 1 & 6 \\
\hline West Waterway & 4 & 1 & 1 & 2 \\
\hline East Waterway & 4 & 0 & 3 & 1 \\
\hline Duwamish River & 11 & 4 & 3 & 4 \\
\hline \multicolumn{5}{|l|}{ Tacoma } \\
\hline Commencement Bay & 6 & 1 & 1 & 4 \\
\hline Hylebos Waterway & 13 & 7 & 1 & 5 \\
\hline Blair Waterway & 9 & 6 & 1 & 2 \\
\hline Sitcum Waterway & 4 & 1 & 1 & 2 \\
\hline City Waterway & 4 & 4 & 0 & 0 \\
\hline Puyallup River & 1 & 0 & 1 & 0 \\
\hline \multicolumn{5}{|l|}{ Bremerton } \\
\hline Sinclair Inlet & 12 & 7 & 1 & 4 \\
\hline \multicolumn{5}{|l|}{ Reference Areas } \\
\hline Port Madison & 6 & 0 & 2 & 4 \\
\hline Birch Bay & 5 & 1 & 2 & 2 \\
\hline
\end{tabular}

at each site. From the available data it must be assumed that two distinct cause and effect relationships have been measured by the cytotoxicity and genotoxicity tests and that no association between the two can be made without further study.

\section{MFO activation}

The data obtained from this portion of the study indicated that all 22 sediment extracts tested were capable of adversely affecting the in vitro reproductive capacity of fish cells provided that the cells possessed an active mixed function oxidase enzyme system. The bluegill (BF-2) cells which did not possess an active MFO system were affected only by the highest concentrations of extracts from five stations. The high concentrations of organic material comprising these positive exposure levels (50-69 $\mu \mathrm{g} /$ $\mathrm{ml}$ ) in the BF-2 cells and the absence of a dose response suggested that non-specific toxicity rather than inhibition of cellular reproduction was the cause. The obvious dose response to increasing concentrations of extract in the rainbow trout cells (RTG-2) which possessed an active MFO system suggested a true adverse but sublethal effect on cell proliferation. This effect apparently resulted from enzymatic conversion of otherwise inert compounds in the extract to toxic intermediates (Chambers \& Yarbrough, 1976; Stegeman, 1981). 
The difference in response that was observed between these two cell lines represents an excellent example of how two similar test systems can produce conflicting results following exposure to the same compound. The results suggest, on a whole organism level, that different species, life cycle stages or populations within a species might also respond dissimilarly to exposure to a given compound as a consequence of the presence or absence of modifying enzyme systems.

Although they are not specific to particular classes of compounds, the sublethal responses detected in the cultured fish cells serve as sensitive direct tests of sediment toxicity. If translated to effects at the whole animal level, these responses might result in such subtle effects as low hatching weight, reduced growth, incomplete organ development or reduction in viable gamete production.

\section{Anaphase aberrations}

Since earlier studies have demonstrated that anaphase aberrations result specifically from exposure of actively dividing cells to genotoxic agents (Kocan et al., 1982), it is reasonable to assume that the damage seen in this study resulted from exposure to similar agents in Puget Sound sediment.

The data collected in this study showed that the areas of highest genotoxic potential were clustered in the urban embayments and waterways where the incidence of neoplastic and pre-neoplastic liver lesions has been noted in benthic fishes. Within a given site (e.g. Elliott Bay) certain subareas were seen to contain a high proportion of significantly genotoxic stations while other subareas were predominantly negative. On the basis of these data, one could develop a map of the site and focus future research on a restricted number of stations.

Among the 43 stations which had high genotoxic potential, one was located within a reference area (Birch Bay). Further study revealed that the site was adjacent to a series of storm drains which collect agricultural and residential runoff.

The ultimate long-term effect on an organism of exposure to low levels of genotoxic agents could manifest itself in the form of reduced growth rate, shortened life span or neoplasia (Beardmore, 1980). If germ cells were selectively affected one might see reduced fecundity, dominant lethal mutations or birth defects; if embryonic tissues were selectively affected one might see juvenile mortality, teratogenesis, low hatching weight or later tumor development (Sinnhuber et al., 1977). The development in recent years of short-term, in vitro cytogenetic assays such as the Ames test (Ames, 1972), the sister chromated exchange test (Latt, 1974) and others has provided toxicologists with tools that will help to unravel the causes of environmentally mediated diseases whose bases lie in damage to genes or to chromosomes. These techniques have already been adapted by some aquatic toxicologists for use with fish (Kligerman et al., 1975; Kocan et al., 1979; Longwell \& Hughes, 1980; Chapman et al., 1982; Landolt \& Kocan, 1983; Hose et al., 1982) and invertebrates (Pesch \& Pesch, 1980; Battaglia et al., 1980; Dixon \& Clark, 1982; Beardmore, 1980). Further refinement of existing assays and development of new ones will provide aquatic toxicologists with a rapid, cost effective approach to the study of the complex mixtures found in water, sediment and the surface microlayer.

At present it would be a formidable task to relate observation of any of the above mentioned changes in fish collected from Puget Sound to specific genotoxic agents. The 
sediment extraction procedure used in this study was limited to organic compounds; thus, the effects of inorganic substances (e.g. metals) and physical agents were undetectable, as were synergistic effects between organic and inorganic compounds.

In spite of the limitations of the procedure, we feel that in vitro cytological test systems offer marine toxicologists a useful, sensitive, inexpensive tool which can be incorporated into a battery of tests aimed at unraveling the complex causes of environmentally mediated diseases of fish.

Acknowledgements. This research was supported by grants from the Office of Marine Pollution Assessment, N.O.A.A. (NA80RAD00053) and the National Institute of Environmental Health Sciences (5-P30-ES-02190-02). We are grateful to Dr. R. Dexter, E.V.S. Consultants, Seattle, Washington for performing the chemical extractions and to Ms. K. Sabo for providing technical support for the cell culture portion of the study.

\section{LITERATURE CITED}

Ames, B. N., 1972. A bacterial system for detecting mutagens and carcinogens. In: Mutagenic effects of environmental contaminants. Ed. by H. E. Sutton \& M. I. Harris. Acad. Press, New York, $58-66$.

Battaglia, B., Bisol, P. M., Fossato, V. U. \& Rodino, E., 1980. Studies on the genetic effects of pollution in the sea. - Rapp. P. -v. Réun. Cons. int. Explor. Mer 179, 267-274.

Beardmore, J. A., 1980. Genetical considerations in monitoring effects of pollution. - Rapp. P. -v. Réun. Cons. int. Explor. Mer 179, 258-266.

Chambers, J. E. \& Yarbrough, J. D., 1976. Xenobiotic transformation systems in fishes. - Comp. Biochem. Physiol. 55C, 77-84.

Chapman, P. M., Vigers, G. A., Farrell, M. A., Dexter, R. N., Quinlan, E. A., Kocan, R. M. \& Landolt, M. L., 1982. Survey of biological effects of toxicants upon Puget Sound biota. I. Broad-scale toxicity study. - NOAA tech. Memo. OMPA-25, 1-98.

Dexter, R. N., Anderson, E. D., Quinlan, E. A., Goldstein, L. S., Strickland, R. M., Pavlou, S. P., Clayton, J. R., Kocan, R. M. \& Landolt, M. L., 1981. A summary of knowledge of Puget Sound related to chemical contaminants. - NOAA tech. Memo. OMPA-13, 1-435.

Dixon, D. \& Clark, K. R., 1982. Sister chromatid exchange; a sensitive method for detecting damage caused by exposure to environmental mutagens in the chromosomes of adult Mytilus edulis. Mar. Biol. Lett. 3, 163-172.

Hose, J. E., Hannah, J, B., DiJulio, D., Landolt, M. L., Miller, B. S., Iwaoka, W. T. \& Felton, S. P., 1982. Effects of benzo(a)pyrene on early development of flatfish. - Archs environ. Contam. Toxicol. 11, 167-171.

Kligerman, A. D., Bloom, J. E. \& Howell, W. S., 1975. Umbra limi: A model for the study of chromosome aberrations in fish. - Mutat. Res. 31, 225.

Kocan, R. M., Landolt, M. L. \& Sabo, K. M., 1979. In vitro toxicity of eight mutagens, carcinogens on cultured fish cells. - Bull, environ. Contam. Toxicol. 23, 269-274.

Kocan, R. M., Landolt, M. L. \& Sabo, K. M., 1982. Anaphase aberrations: A measure of genotoxicity in mutagen-treated fish cells. - Environ. Mutagenesis 4, 181-189.

Landolt, M. L. \& Kocan, R. M., 1983. Fish cell cytogenetics: A measure of the genotoxic effects of environmental pollutants. In: Aquatic toxicology. Ed. by J. O. Nriagu. Wiley, New York, $335-353$.

Latt, S. A., 1974. Sister chromatid exchanges, indices of human chromosome damage and repair: detection by fluorescence and induction by mitomycin C. - Proc. natn. Acad. Sci. U.S.A. 71, 3162-3166.

Longwell, A. C. \& Hughes, J. B., 1980. Cytologic, cytogenetic and developmental state of Atlantic mackeral eggs from sea surface waters of the New York Bight, and prospects for biological effects monitoring with ichthyoplankton. - Rapp. P. -v. Réun. Cons. int. Explor. Mer 179, 275-291.

Malins, D. C., McCain, B. B., Brown, D. W., Sparks, A. K. \& Hodgins, H. O., 1980. Chemical 
contaminants and biological abnormalities in Central and Southern Puget Sound. - NOAA tech. Memo. OMPA-2, 1-295.

McCain, B. B., Pierce, K. V., Wellings, S. R. \& Miller, B. S., 1977. Hepatomas in marine fish from an urban estuary. - Bull. environ. Contam. Toxicol. 18, 1-2.

Nichols, W. W., Miller, R. C. \& Bradt, C., 1977. In vitro anaphase and metaphase preparations in mutation testing. In: Handbook of mutagenicity testing procedures. Ed. by B. J. Kilbey, M. Legator, W. Nichols \& C. Ramel. Elsevier, New York, 225-234.

Pesch, G. \& Pesch, C. E., 1980. Neanthes arenaceodentata (Polychaeta: Annelida), a proposed cytogenetic model for marine genetic toxicology, - Can. J. Fish. aquat. Sci. 37, 1225-1228.

Pierce, K. V., McCain, B. B. \& Wellings, S. R., 1978. Pathology of hepatomas and other liver abnormalities in English sole (Parophrys vetulus) from the Duwamish River Estuary, Seattle, Washington. - J. natn. Cancer Inst. 60, 1445-1453.

Sinnhuber, R. O., Hendricks, J. D., Wales, J. H. \& Putman, G. B., 1977. Neoplasms in rainbow trout, a sensitive animal model for environmental carcinogenesis. - Ann. N. Y. Acad. Sci. 298, 389-408.

Stegeman, J. J., 1981. Polynuclear aromatic hydrocarbons and their metabolism in the marine environment. In: Polycyclic hydrocarbons and cancer. Ed. by H. V. Gelboin \& P. O. P. Ts'o. Acad. Press, New York, $60 \mathrm{pp}$. 